\title{
François Bordes in rojstvo (popolne) tipologije kamnitih orodij Francois Bordes and the Birth of the (perfect) Stone Tools Typology
}

\author{
Boris Kavur \\ Univerza na Primorskem, Slovenija \\ boris.kavur@upr.si
}

Le malo arheologov je v drugi polovici dvajsetega stoletja tako vplivalo na razvoj metodologije arheološkega dela ter interpretacije prazgodovine kot François Bordes. Na eni strani je sicer pomembna njegova raziskovalna usmeritev v izboljšanje terenskih tehnik raziskav, predvsem pa je revolucionarna njegova standardizacija tipoloških opisov kamnitih orodij oziroma razvoj statističnih metod za primerjavo rezultatov analiz iz posameznih kontekstov. Prav na osnovi njegovega dela razumemo, da je potrebno opazovati dva vidika variabilnosti arheoloških zapisov - formalno tipološko variabilnost kamnitih orodij znotraj konteksta ter variabilnost v relativnih pogostnostih tipih orodij med različnimi plastmi oziroma najdišči. Danes, ko so številne njegove interpretacije zastarele oziroma neustrezne, se moramo zavedati kontekstov, v katerih so nastale, ter raziskovalnih vprašanj, na katera so pomagale odgovoriti. Ključne besede: stara kamena doba, kamnita orodja, tipologija orodij, tehnologija izdelave orodij, zgodovina arheologije

Few archaeologists in the second half of the twentieth century influenced the development of the methodology of archaeological work and the interpretation of prehistory as much as François Bordes. On the one hand, his research orientation towards the improvement of field research techniques is important, but above all his standardization of typological descriptions of stone tools and the development of statistical methods for comparing the results of analyzes from individual contexts are revolutionary. It is on the basis of his work that we understand the need to observe two aspects of the variability of archaeological records - formal typological variability of stone tools within the context and the variability in the relative frequencies of these types of tools between different layers or sites. Today, when many of his interpretations are outdated or inadequate, we need to be aware of the contexts in which they arose and the research questions they helped answer.

Keywords: Palaeolithic, stone tools, tool typology, technology of tool production, history of archaeology

\section{Uvod, dolg skoraj stoletje}

$\mathrm{R}$ azmišljujoč o starokamenodobni arheologiji ne smemo pozabiti, da srednji paeolitik ne predstavlja kulturnega obdobja v arheološki sistematiki materialnih ostankov hominidov, ki so čakali, da bi postali moderni, ampak je širok in variabilen pojav - tako v času, prostoru kot tudi v različnih okoljih (Kuhn 1995, 5). Prav zaradi svoje kompleksnosti je desetletja predstavljal eno izmed področij raziskav, na katerem so se oblikovale in falsificirale velike teorije, ki so zaznamovale arheologijo druge polovice prejšnjega stoletja, pravzaprav predstavlja prav tisto področje, na katerem sta bili rojeni tako so- 
dobna kamenodobna arheologija kot tudi teoretična arheologija.

Ker do sredine 19. stoletja ni bilo raziskovalne metodologije oziroma arheološke teorije (oziroma sploh ni bilo prazgodovinske arheologije kot take), ki bi omogočala opisovanje kamnitih orodij onkraj lapidarnih etnografskih paralel in funkcionalnih hipotez, postavljenih na osnovi njihove oblike, so kulturne delitve mlajšega pleistocena, oziroma najdišč, temeljile predvsem na analizah favnističnih ostankov. Tako je prelomni interpretacijski okvir leta 1869 ustvaril Gabriel de Mortillet, ko je po paleontoloških shemah Edouarda Larteta opisal francoski paleolitik - njegov opis je prvi temeljil samo na stratigrafskih opazovanjih in opisovanjih arheoloških ostankov. Po najdišču iz vasi Peyzac-le-Moustier v doline reke Vézère je obdobje poimenoval »Epoque de le Moustier « in ga uvrstil med acheuléen in solutréen (Dibble in Rolland I992, 2). Nekaj let kasneje, leta I883, je v pojasnilu kot moustérienske opredelil vse tiste kamnite industrije, ki so podobne najdbam $\mathrm{z}$ najdišča Le Moustier ter imajo kamnita orodja večinoma izdelana na odbitkih (Beyries 1987, 5). Ločil jih je od prejšnjih obdobij chelléena in acheuléena zaradi odsotnosti predhodno najprepoznavnejših oblik orodij, to je pestnjakov. Mlajša obdobja pa je ločil predvsem zaradi boljše obdelave orodij iz kamna ter izdelave orodij iz kosti. Za obdobje naj bi bile po njegovi delitvi značilni enostransko obdelane moustérienske konice, strgala in pestnjaki, ki pa naj bi bili tanjši od staropaleolitskih (Binford in Binford 1983, 7I). De Mortilletov pregled je tako podajal enolinijsko razvojno shemo tehnologije oziroma človeške kulture skozi kvartar (Dibble in Lenoir 1995a, 8), poglavitno novost pa so predstavljala njegova sistematična opazovanja fizičnih in tehnoloških lastnosti kamenih orodij. S slednjimi je v arheologijo jasno uvedel koncepte arheološke tipologije ter kulturnozgodovinskih interpretacij, utemeljenih na tipoloških opazovanjih. Ko pa je s povečanjem količine poznanih najdb na koncu prejšnjega in $\mathrm{v}$ začetku tega stoletja zazdelo, da so srednjepaleolitske industrije dokaj homogene po vsej Evropi, se je povsod prevzela francoska kulturna (in tudi tipološka) terminologija (Beyries 1987, 5).

Po de Mortilletu je prve poskuse sistematike opisovanja (in razlaganja) moustériena v Franciji v začetku tega stoletja objavil Victor Commont, ki je raziskoval paleolitik pokrajine ob reki Sommi v severni Franciji. Na osnovi svojih opazovanj rečnih teras in puhlic ter tedaj poznane in popularne sheme alpskih poledenitev je sestavil kronološki sistem razvoja francoskega moustériena. Definiral je obstoj »toplodobnega « moustériena, ki ga je zaznamovala prisotnost toplodobne favne in ki naj bi obstajal $\mathrm{v}$ zadnjem interglacialu (moustérien à faune chaude). Temu naj bi sledil starejši moustérien (moustérien ancien), za katerega naj bi bili značilni veliki levallois odbitki, trikotni pestnjaki, strgala in orodja $\mathrm{z}$ izjedo. Temu naj bi sledil srednji moustérien (moustérien moyen) z daljšimi in tanjšimi odbitki levallois, vseboval pa naj bi tudi redke pestnjake ter veliko strgal. Najmlajši pa naj bi bil mlajši moustérien (moustérien supérieur), ki naj bi vseboval še tanjše in daljše odbitke levallois, prav tako pa naj bi vseboval več strgal (predvsem strgala s stopnjevito školjkasto retušo), vendar nobenih pestnjakov (Tuffreau idr. 1981, 294). Njegova shema delitve je bila še vedno zasidrana v starejših geoloških konceptih, ki so namesto variabilnosti predvidevali enolinijski razvoj od starejšega do mlajšega paleolitika (Dibble in Rolland 1992, 2; Dibble in Lenoir 1995a, 9), vendar pa je pokazal visoko stopnjo razumevanja oziroma upoštevanja tehnološke in tipološke specifike kamnitih orodij. Kljub zagonu kulturnega evolucionizma v začetku 20. stoletja so s koncem Commontovega delovanja prav tako zamrle ideje o linearnem razvoju kamenih orodij.

Kmalu po Commontovih objavah in $\mathrm{v}$ duhu evolucionistične teorije abbéja Henryja Breuila je Denis Peyrony podal teorijo o obstoju dveh istočasnih orodnih tradicij znotraj moustériena - različni glede na tipologijo kamnitih orodij naj bi predstavljali izdelke dveh paralelnih rodov (Bordes I950b, 394). Definiral je klasični (tipični) moustérien, ki naj bi vseboval mnogo strgal in moustérienskih konic ter mo- 
ustérien z acheuléensko tradicijo, ki naj bi vseboval pestnjake in nože s hrbtom (Beyries 1987, 6). Predvsem pri slednjih je povezal orodne tipe, za katere je že leta I9ıo Gaston Lalanne ugotovil, da se v orodnih inventarjih nahajajo skupaj. Sočasnost teh dveh tradicij je dokazoval s sočasnostjo favne na najdiščih Le Moustier in La Ferrassie, ki pa sta imeli izrazito različna kamnita orodja (Mellars 1969, I4I).

Kasneje je v svojih delih Peyrony idejo o dveh vzporednih orodnih tradicijah ter dveh rodovih razširil tudi na mlajši paleolitik - na aurignacien in spodnji perigordien, ki naj bi bila izdelka dveh različnih človeških ras (ene z najdišča Combe-Capelle in druge z najdišča Cro Magnon). Prva rasa naj bi izdelovala kamena orodja $s$ hrbtom (châtelperronien in gravattien v Evropi ter capsian $\mathrm{v}$ Afriki - sem naj bi zraven skeleta s Combe-Capelle sodile še najdbe skeletnih ostankov z Mecha-El Arbi, Aïn Métherchem in skelet iz Olduvaja, ki ga je odkril Hans Reck), druga rasa pa aurignacien (Lacorre in Lacorre 1953, 260-63; Harrold 1988, 158).

Podobno je tudi abbé Henry Breuil možnost vzporednega obstoja dveh ras dokazoval na najdbah starejšega paleolitika, kjer je definiral kulturo z orodji na odbitkih, ki naj bi bila izdelek ene, in kulturo z orodji na odbitkih in pestnjaki, ki naj bi bila izdelek druge rase. Obe, clactonien in acheuléen, naj bi bili po njegovem prepričanju sočasni (Bordes 1950b, 394; Tuffreau idr. I98I, 296). Razlagal je, da naj bi se iz clactoniena razvila tayacien in levalloisien. Skupaj z acheulénom naj bi te tri kulture povzročile razvoj različnih variant $\gg$ jamskega moustériena « (Dibble in Rolland 1992, 3; Dibble in Lenoir I995a, 9).

$\mathrm{V}$ tem obdobju se je avtorjem, kot so bili $\mathrm{H}$. Breuil, D. Peyrony in M. Burkit zdelo, da orodni inventarji variirajo $\mathrm{v}$ času in prostoru, kar jih je lahko vodilo $k$ ideji, da različni orodni skupki s svojim prostorom razširjenosti predstavljajo različne sociokulturne enote (rase, ljudstva, rodove) (Isaac 1989, 339). Peyrony je za kronološko opredelitev najdišč iz orodnih zbirov izbiral orodja, ki jim je pripisoval večjo pomembnost pri kulturni in kronološki opredelitvi. Po vzorcu, ki se je uporabljal v paleontologiji, kjer so za določeno obdobje vodilni posamezni fosili, je ta značilna orodja imenoval »vodilna orodja $\ll$ - fosilles directeurs (Rigaud in Simek 1987, 53). Zaradi prevelike vneme pri najlepše izdelanih orodjih je včasih zavrgel slabše izdelana in s tem napačno prikazal celoten kulturni inventar. Tako je najdbe iz plasti II do V na najdišču Combe-Capelle Bas opredelil kot moustérien tipa La Ferrassie. M. Bourgon pa je na osnovi nizkega indeksa levallois najdbe iz Peyronyjeve plasti IV opredelil kot moustérien tipa La Quina (Dibble in Lenoir I995a, 22-23). Revizijska izkopavanja so pokazala, da je Peyrony iz orodnega inventarja izbral le močno retuširana lepa strgala, ki jih je naknadno analiziral in shranil. H. Dibble in M. Lenoir sta pri reviziji ugotovila, da je treba vso najdišče v resnici kulturno uvrstiti v tipični moustérien po Bordesovi shemi (Dibble in Lenoir 1995b, I67I73).

\section{Desetletji množice interpretacij}

Ta kratek pregled dogajanja v prvi polovici stoletja kaže prepričanje znanstvenikov, da sta obstajali dve vzporednih kulturni tradiciji, katerih nosilca sta bili dve različni vrsti ljudi. To je veljalo v antropologiji do leta 1927 , ko je v londonskem Royal Anthropological Institute na češkem rojeni ameriški fizični antropolog A. Hrdlička predstavil predavanje »Neandertalsko obdobje človeštva«, kjer je zatrdil, da je nosilec moustériena samo neandertalec. Napadal je idejo, da so neandertalce zamenjali moderni ljudje, ki naj bi bili nosilci aurignaciena, ampak je trdil, da se moustérien razvil v aurignacien oziroma da so se neandertalci razvili v anatomsko moderne ljudi (Tattersall I995, 50).

Povojno obdobje je zaznamovalo vedno večje oddaljevanje od geoloških konceptov in vzpostavitev arheološke sistematike $\mathrm{z}$ neodvisno kronološko in kulturno delitvijo. Začelo se je leta 1956, ko je Gordon Childe kritiziral paleolitske raziskave. Po njegovem mnenju je bilo nevzdržno, da je arbitrarna kronološka delitev paleolitskih kultur temeljila na delitvi pleistocena, ki pa v svoji osnovi ni kulturne narave. Predlagal je 
tudi drugačno poimenovanje za paleolitske kulture. Menil je, da bi bilo treba starejši in srednji paleolitik združiti v archaeolithic, kjer so orodja izdelana iz jeder in odbitkov, ter v mlajši paleolitik in mezolitik, ki naj bi predstavljala tako miolithic kot leptolithic, kjer so orodja narejena iz klin (Rolland I990, 350). V tem času je prišlo tudi do delitve interesnih področij. Če so pred sredino petdesetih let vsi raziskovalci moustérien obravnavli kot stopnjo med starejšim in mlajšim paleolitikom, se je na začetku petdesetih let pojavila skupina raziskovalcev, ki so se usmerili $\mathrm{k}$ raziskovanju notranje dinamike nekega kulturnega obdobja. Prvi, ki se je natančneje ukvarjal s to problematiko, je bil M. Bourgon, ki pa je žal umrl leta 195ı, tako da je njegovo delo o moustérienu v Perigordu posthumno leta 1957 izdal F. Bordes (Dibble in Lenoir 1995a, 2I). Obdobje raziskovanj, ki je prihajalo, je najbolje opisala Bourgonova misel: »Les hommes préhistoriques ont oublié de simplifier la prébistoire.«

Leto dni za tem, ko je Bordes izdal svoj Essai de classification des industries »moustériennes «, je L. Pradel pri pregledu tega delil na dva dela na moustérien in levalloisien (Pradel 1954, 35) -, pri čemer je njegov opis levalloisiena temeljil na objavi Françoisa Bordesa. Ta je predelal shemo sedmih stopenj levalloisiena Breuila (Bordes, I953C, 226-234) iz katere je prve tri stopnje uvrstil v riški glacial, stopnjo IV v interglacial Riss/ Würm in zadnje tri stopnje v starejši Würm. V stopnji VI naj bi se v orodnih inventarjih nahajalo le še malo pestnjakov, v stopnji VII pa že veliko mlajšepaleolitskih elementov (Breuil in Kelly I954, 24-25). Sam termin levaloisien je leta I93I definiral $\mathrm{H}$. Breuil za industrije iz puhlic v dolini reke Somme, ki jih je V. Commont opredelil kot moustérien. Po Bordesu naj bi se pojavil v riškem glacialu pred pojavom jamskega moustériena (moustérien des grottes), ki naj bi po Peyronyju vseboval obliko s pestnjaki in drugo brez njih, kar je bil spet odsev korenin iz clactoniena in acheuléena (Dibble in Lenoir I995a, 9). Bordes ga je delil na tri dele, glede na pozicijo najdišč na terasah Somme (Bordes 1953c, 226-27) - starejši levalloisien (stopnji I in II), srednji levalloisi- en (stopnji III in IV) in mlajši levalloisien (stopnje V do VII).

Po kulturni delitvi naj bi stopnja $\mathrm{V}$ še sodila v acheuléen, stopnji VI in VII, kjer spremljajoči pestnjaki postajajo redki, pa je bila sočasna že z jamskim moustérienom. Pri tem je opazil, da se v jamskem moustérienu včasih nahajajo orodni inventarji $\mathrm{z}$ več fasetiranimi taloni kot $\mathrm{v}$ levalloisienu. To razliko je pojasnil s številom neretuširanih odbitkov levallois na najdiščih. Ti odbitki so v puhličnih najdiščih pogosti, v jamah pa jih je malo (Bordes I953C, 226-34). Pri tem je tudi obračunal s starim prepričanjem Commonta, ki je fasetiran talon odbitka enačil s tehniko levallois. Bordes je dokazal, da vsi odbitki levallois nimajo fasetiranega talona in da vsi odbitki s fasetiranim talonom niso izdelani s tehniko odbijanja levallois (Bordes I988, 26). Nekaj mesecev za tem je definiral oblike odbitkov levallois (Bordes I953d, 3II) - prave odbitke levallois ovalne oblike, kline levallois, ki so $\mathrm{v}$ resnici podaljšani odbitki, ter konice levallois, ki so trikotni odbitki. Prav tako je opomnil, da bi bile konice psevdolevallois lahko produkti popravila jeder (Bordes, 1953d, 313).

Tako se je znašel pred problemom, ko kljub prisotnosti tehnike levallois $\mathrm{v}$ jamah ni bilo pravega levalloisiena. Zato je izdelal shemo, kjer je primerjal oblike moustériena in levalloisiena ter ugotovil, da gre za tri zvrsti, ki se pokrivajo oziroma vsaka zvrst moustériena ustreza eni obliki levalloisiena (Bordes I953c, 228-234) - tipični moustérien ustreza levalloisienu VII (Le Moustier plast J, Houpeville »série claire «), moustérien $\mathrm{z}$ acheuléensko tradicijo ustreza levalloisienu V (Gare de Couze spodnja plast, Houpeville »série rousse《) ter nazobčani moustérien, ki ustreza levalloisienu. Žal pri osnovni definiciji ni podal, kot pri drugih dveh, natančnejših referenčnih najdišč in plasti. Pravzaprav je bil slednji v njegovem opusu vedno nekoliko obstranskega pomena oziroma manj diskutiran, kar se je preneslo tudi na njegove kritike in naslednike. V ozadju več desetletij trajajočega problema najverjetneje tiči dejstvo, da je svojo veliko razpravo o nazobčanem moustérienu objavil v reviji 
ki za francosko, pa tudi mednarodno, prazgodovino ni bila najreferenčnejša za preučevanje paleolitika - v Arheološkem vestniku (Bordes 19621963, 43-49).

Opazujoč objave lahko sledimo razvoju Bordesovih misli ter samo dinamiko objavljanja, ki je bila izjemno hitra. Medtem ko se je članek, v katerem je uporabljal različne zvrsti moustériena nahajal v 4 zvezku Bulletin de la Sociétéprehistorique française (Bordes $1953 \mathrm{C}$ ), je natančnejšo definicijo moustérienskih skupin podal v zvezku 7-8 iste revije (Bordes, 1953e, 457-66). S starejšim levalloisienom pa je obračunal že prej, ko je ugotovil, da pred zadnjim glacialom ne obstaja kultura levalloisien, ampak le tehnika levallois, ki je sestavni del razvitga acheuléena oziroma dela te kulture. Ne obstaja namreč najdišče, ki bi bilo starejše od Würma in bi vsebovalo le levalloisien ter nobenega pestnjaka (Bordes 1952b, 556).

Ostala mu je le še razlaga obitkov levallois, ki so po njegovem mnenju predstavljali polizdelke in ne orodij. Plana najdišča, kjer je bilo veliko odbitkov, je razložil z dejstvom, da so ljudje živeli v krajih, kjer je bilo veliko kremena, kot nomadi in so namenoma puščali polizdelke na krajih, kamor so se občasno vračali. Kajti bilo jih je lažje predelati v orodja, kot pa jih ves čas nositi s sabo. Drugače naj bi bilo v jamah, kjer so živeli bolj ustaljeno življenje in so ostajali na enem kraju dlje časa. Zato niso nosilis sabo veliko orodij in so jih vedno znova obdelovali, ko so se vračali v jamo. $\mathrm{Na}$ osnovi tega je menil, da moramo pričakovati, da bodo na ozemlju, bogatem s kremenom, odkrili več najdišč z levalloisienom na planem, medtem ko se bo v jamah nahajal moustérien. Iz tega je izpeljal, da način življenja določa tehnologijo izdelave kamenih orodij in ne tradicija (Bordes I953C, 232). Prav tako pa je menil, da bi bile te variacije lahko tudi posledica sezonskega načina življenja oziroma da bi bil levalloisien na platojih okoli Les Eyzies lahko odraz poselitve poleti, pozimi pa je vreme ljudi potisnilo $\mathrm{v}$ jame $\mathrm{v}$ dolini, kjer so za sabo pustili moustérien (Bordes I953C, 233). Ne zgolj metodološko, ampak tudi interpretativno je povzročil pomik naprej - posledično sta H. Dibble in M. Lenoir opozorila, da smo že pri prvi veliki Bordesovi objavi te problematike priča dejstvu, da je za variabilnost v orodnih inventarjih najprej krivil način življenja in ne kulturne tradicije ter se $s$ tem oddaljil od Breuilove sheme, ki je levalloisien in moustérien postavljala kot dve ločeni kulturi (Dibble in Lenoir 1995a, Io).

Tehnologija odbijanaj levallois je bila prepoznana kot ena izmed najbolj izstopajočih značilnosti srednjega paleolitika vse od časa originalne definicije moustériena Gabriela de Mortilleta s konca 19. stoletja. Osrednja in diagnostična značilnost slednje je bila težnja po kontroli oziroma predpripravi oblike in velikosti odbitka, ki je bila dosežena z natančno pripravo jedra. Gre za vprašanje, ki se mu je posvečal celo življenje, predvsem zaradi zavedanja, da je zaradi množice oblik odbitkov in jeder koncept $\mathrm{z}$ leti postajal vse konfuznejši (Bordes 1952b; Bordes I955a). V svojem zadnjem delu je poskusil še zadnjič opozoriti, da je tehnika levallois, ki omogoča izrabo številnih oblik predpripravljenih jeder ter producira številne oblike odbitkov - od »klasičnih« širokih ovalnih konvergirajočih odbitkov, izvirajočih iz centripetalno obdelanih jeder, do bolj podolgovatih koničastih oblik, ki jih lahko opisujemo kot konice levallois ali celo kline, pač glede na to, kašne morfološke kriterije uporabljamo za definicijo (Bordes I980).

Prav tako pa ni zanemarjal pomena dostopnosti surovine v pokrajini pri vlogi izdelave tipov kamenih orodij. Po njegovem mnenju bi pleme, ki je izdelovalo orodja levallois in se je preselilo na ozemlje s kvalitetnim kremenom, še naprej izdelovalo omenjena orodja, $\mathrm{v}$ primeru pa, da bi se preselilo v pokrajino, kjer taki viri niso bili dostopni, bi s to tradicijo prenehalo in levallois odbitki bi izginili iz arheološkega zapisa (Bordes I95ob, 413). Delno je tako prepričanje sovpadalo z mnenjem, da naj bi podnebje definiralo način obnašanja in preko tega tudi način izdelave orodij. Avtorji pred Bordesom, ki so zaradi pomanjkanja sistema za definicijo variabilnosti jamski moustérien pojmovali kot dokaj monotono industrijo brez variacij, so to lastnost opisovali kot posledico hladnega in vlažnega podnebja, v kate- 
rem naj bi bila stiska ljudi zelo velika in se zaradi tega tehnika izdelovanja orodij ni razvijala (Pradel 1950, 256). Potrditev svojih hipotez je Bordes videl v Commontovih izsledkih iz Picardije iz leta 1913. Commont je na najdiščih Roisel, Marlers in Busigny opazil, da so orodja na krajih, kjer je več kremena, manj izrabljena in retuširana. $\mathrm{V}$ nasprotju pa so na najdiščih, kjer so viri surovine oddaljeni, majhna, močno retuširana in izrabljena ter zelo podobna tistim v jamah Spy, Le Moustier in La Ferrassie (Bordes 1953C, 233).

\section{Večji kot v resnici}

Bordes je ustvaril sodobno sistematiko razmišljanja v paleolitski (ter analitski) arheologiji druge polovice 20. stoletja. Najprej je kot neustrezne pokazal ključne interpretacije arheologije in antropologije začetka stoletja - ovrgel je teorijo o paralelnem obstoju dveh kulturnih tradicij $\mathrm{s}$ tem, da je prikazal stratigrafske težave $\mathrm{v}$ Breuilovih zaključkih. Zaključil je, da so industrije s pestnjaki delo vrste Homo sapiens iz interglaciala, medtem ko so orodja na odbitkih nastala v glacialu (Bordes i950b, 395-397). V zamenjavo je predlagal teorijo razvoja zvrsti moustériena, ki ga je ponazoril v obliki grma, v katerem se iz izvorne točke industrije cepijo ter dosegajo svojo maksimalno razvejanost (Bordes 1950b, 409-4II). V tej točki se je ujel v lastno mrežo izdelovalca pestnjakov je poimenoval Homo sapiens, pri čemer se je oprijel teorije, da naj bi se pripadniki te vrste v Evropi nahajali že od starejšega pleistocena dalje (Piltdown, Swanscombe, Fontéchevade) in obstajali vzporedno z neandertalci (Pottier 1951, 343). Teorija, da je staropaleolitski hominid anatomsko moderen, je vsebovala predpostavko o vzporednem obstoju, ki jo je Bordes izgnal iz arheologije. Istočasno so antropologi namreč že sprejeli njegove argumente in stara prepričanja preoblikovali v model, po katerem staropaleolitski hominidi, ki so modernemu človeku sicer anatomsko podobni, ne predstavljajo več naših neposrednih prednikov. Prav tako to niso niti neandertalci, ampak so oboji le stranski veji v razvoju človeka (Jullien I95I, 473). Tako je pod Bordesovim vplivom antropologija iz dveh vzporednih linij razvoja človeka naredila prikaz v obliki grma s stranskimi vejami, ki so prikazovale potek razvoja človeka.

Svoje prepričanje v zvezi s srednje- in mlajšepaleolitskimi hominidi je Bordes razložil dve leti kasneje. Pri tem se je spet skliceval na očiten razvoj na kraju samem, pri katerem naj bi se iz moustériena razvil mlajši paleolitik. Za ta prikaz je jasno, da zveza, kot jo je podal A. Hrdlička, ki je enačil moustérien in neandertalce, ne drži, podprl pa je njegove ideje o razvoju modernega človeka iz neandertalca. Po Bordesovem mnenju namreč ni res, da orodja na odbitkih delajo samo neandertalci in orodja na klinah samo moderni ljudje, saj so fosili, kot je Fontechévade, ki niso ne pravi Homo sapiens pa tudi ne neandertalci, izdelovali orodja na odbitkih. Prav tako naj bi bil moderni človek iz Combe-Capelle, po Bordesovem mnenju, odkrit v plasti $\mathrm{z}$ industrijo $\mathrm{z}$ močnimi srednjepaleolitskimi značilnostmi (Bordes i952a, 442-45). Zato je menil, da »ti ljudje niso padli z neba popolnoma oboroženi s périgordiensko industrijo.«. Kar pomeni priznanje prehoda iz srednjega $\mathrm{v}$ mlajši paleolitk $\mathrm{v}$ zahodni Evropi, kjer je poznana celo prehodna industrija (périgordien I), namesto da bi po starem načelu $\gg$ Ex oriente lux «, ki morda drži za neolitik, izvor te spremembe iskali v oddaljenih in neznanih krajih, kot sta Iran in Pamir (Bordes 1952a, 444). Pri tem je razvidno, da je kljub odpravi paralelizma v arheologiji verjel, da je antropološki paralelizem obstajal ter da je ob koncu srednjega paleolitika eno izmed ljudstev prevladalo nad ostalimi in izrinilo starejše moustérienske skupine. V svojih poznih delih pa je, kot je napisal v zborniku konference Unesca, ki ga je sam uredil in je bil posvečen okoljskim spremembam ter izvoru Homo sapiens, domneval, da so prehodi iz srednjega paleolitika potekali sinhrono na vsaj šestih krajih po svetu (Bordes 1971; Bordes 1972a; Bachellerie idr. 2012).

Največje uspehe pa je dosegel, ko je sestavil in kasneje skupaj z Bourgonom dopolnil standardizirano tipološko listo kamenih orodij z opisi tehnologij za izdelavo teh tipov. Bila je tako široko zasnovana, da je še danes uporabna tudi za 
opisovanje moustériena z območij, ki jih niso zajele njune študije (Dibble 1988, I8I). Prva tipologija je vsebovala samo 40 tipov orodij, I2 tipov pestnjakov in 9 tipov jeder (Bordes 1950c, 26), kasneje pa sta jo zaradi neustreznosti razširila na 6r tipov (Bordes in Bourgon I951a, 3-23). Pravzaprav so sklepi, ki so vodili k nastanku tipološke liste kamenih orodij iz starejšega in srednjega paleolitika, nastajali počasi skozi serijo člankov, kjer je pod naslovom »Notules de Typologie paléolithique« obravnaval posamezne probleme izdelave in tipologije orodij (Bordes 1953b, 22426; Bordes 1953d, 311; Bordes 1954, 336-38). Kasneje je k njegovi tipologiji Alain Rodrigue pripomnil le to, da bi bilo treba zamenjati vrstni red tipa 4 (retuširana konica levallois) in tipa s (konica psevdolevallois). $S$ tem bi se v skupini levallois (skupina I) zbrala vsa orodja brez retuširanega roba, v moustérienski skupini (skupina II) pa vsa orodja $\mathrm{z}$ retuširnim robom (Rodrigue 1989 , IOO).

$\mathrm{V}$ svoji razpravi o razdelitvi moustériena je leta 1953 definiral tri glavne skupine, pri čemer je drugo in tretjo razdelil na dva dela glede na relativno število strgal $v 75$ orodnih inventarjih s 40 najdišč (Bordes I950c, 25-28; Bordes I953e, 458). Nekoliko drugačno štiridelno delitev sta naredila že dve leti prej z Bourgonom (Bordes in Bourgon 1951a, 22-23), ko sta ga razdelila na moustérien $\mathrm{v}$ pravem pomenu besede, ki vključuje tipični moustérien in moustérien $\mathrm{z}$ acheulénsko tradicijo; charentien, ki vključuje moustérien tipa La Quina in moustérien tipa La Ferrassie; nazobčani moustérien ter tayacien, ki je predwürmski moustérien.

Relativno število strgal predstavlja indeks strgal, ki pomeni odstotek strgal od vseh tipološko definiranih orodij v orodnem inventarju. $S$ tako metodologijo je težišče raziskav s posameznih orodij, ki so jih $\mathrm{v}$ predhodnem obdobju pojmovali kot vodilne tipe, razširil na celotne inventarje kamenih orodij oziroma na relativne zastopanosti posameznih tehnoloških in tipoloških elementov $v$ teh skupkih. Tako je namesto prisotnosti in odsotnosti fosilnih tipov uporabljal relativno zastopanost skupin tipov (Dibble
I988, I8I). Kljub svojim interpretacijam je Bordes v bistvu podpiral mnenje, da je mogoče določena orodja uporabiti kot vodilne tipe. Vendar je to mogoče le znotraj posameznih regij oziroma, kot je to on imenoval, »prazgodovinskih provinc $\ll$, v katerih so regionalne kronologije dobro definirane in je znana pozicija posameznih tipov orodij znotraj teh kronologij. S tem je ugovarjal mnenju A. Vayson de Pradenna in H. Moviusa, ki sta tako možnost zanikala. Vayson je namreč v svojem pregledu leta 1922 namesto celotne oblike orodja uporabil zgolj oblikovanje delovnega roba, kar ga je vodilo do sklepa, da se isti »tipi« pojavljajo v celotni kameni dobi in zato niso kronološko uporabni (Vayson 1920, 455-72). Movius, ki pa je arheologijo pojmoval kot neke vrste »paleo etnologijo «, ki je v svoji zasnovi družboslovna znanost in ne premore svojega metodološkega aparata za določanje relativne starosti, je menil, da lahko za določanje starosti arheoloških orodij uporabimo le geološke podatke o

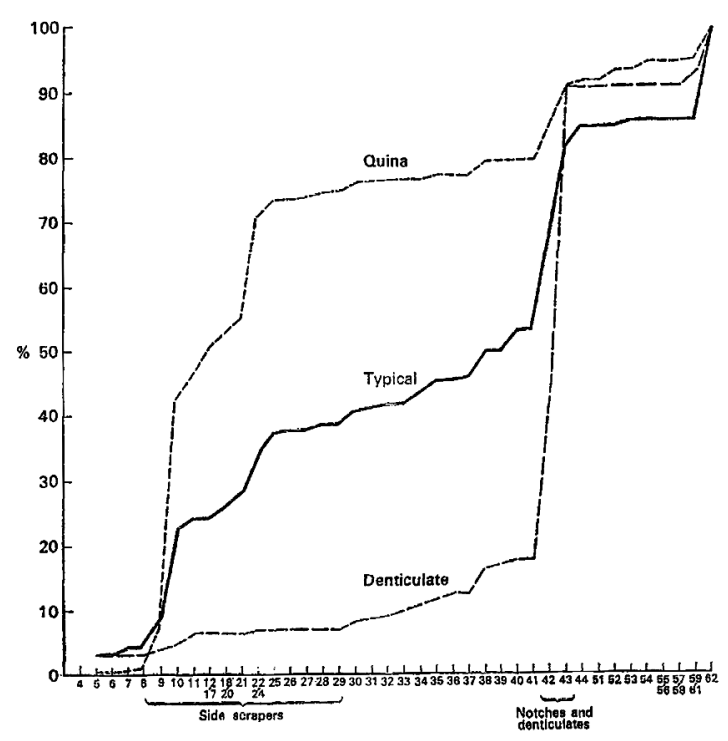

Slika ı. Slika prikazuje kumulativne krivulje treh glavnih zvrsti moustériena jugozahodne Francije po Bordesu. Spodnja krivulja kaže nazobčani moustérien, srednja tipičnega in zgornja moustérien tipa La Quina. (Na vertikalni osi so nanešeni odstotki seštevka orodij v orodnem inventarju, na horizontalni osi pa so navedene številke orodnih tipov.) (Mellars 1996a, 173) 
stratigrafiji (Bordes I950a, 242-45). Zaradi tega je bilo nujno, da je Bordes skušal definirati delitev predmeta preučevanja - moustérien.

Še najnatančneje bi Bordesovo metodologijo delitve zvrsti moustériena opisali, če bi trdili, kot N. Rolland, da njegove zvrsti temeljijo na polimodalnosti grafov distribucij strgal in dodatkov specifičnih oblik orodij (pestnjakov, nazobčanih orodij, mlajšepaleolitskih elementov) (Rolland 1990, 360).

Kot je vidno v spodnji tabeli, je Bordes v prvo skupino uvrstil orodne inventarje, ki so imeli več kot $55 \%$ strgal, v drugo tiste z 22 do 40 $\%$ strgal in v tretjo tiste $\mathrm{z}$ manj kot $13 \%$ strgal. Znotraj vsake skupine je ločil dve podskupini na osnovi prisotnosti tehnike odbijanja levallois oziroma pestnjakov. V prvi skupini, ki jo je poimenoval charentien, je ločil moustérien tipa La Ferrassie od moustériena tipa La Quina. Za prvega je značilen indeks levallois od 25 do $30 \%$ in več, ki ga vedno spremljata tudi visok indeks fasetiranih talonov in laminarni indeks (Bordes 1953e, 460-66; Bordes 1961, 805-6; Bordes in de Sonneville-Bordes 1970, 6I-63; Dibble 1988, 182-83; Dibble in Lenoir I995a, 10).

\begin{tabular}{|c|c|c|c|c|}
\hline Skupine & $\begin{array}{c}\text { Zvrsti } \\
\text { kulture }\end{array}$ & $\begin{array}{l}\text { Indeks } \\
\text { strgal }\end{array}$ & $\begin{array}{l}\text { Tipološke } \\
\text { značilnosti }\end{array}$ & $\begin{array}{c}\text { Teh- } \\
\text { nološke } \\
\text { znač. }\end{array}$ \\
\hline I & $\begin{array}{l}\text { tip La } \\
\text { Quina }\end{array}$ & $>55 \%$ & prečna strgala & $\begin{array}{l}\text { nizek } \\
\text { IL, Ilam }\end{array}$ \\
\hline I & $\begin{array}{l}\text { tip La } \\
\text { Ferras- } \\
\text { sie }\end{array}$ & $>55 \%$ & $\begin{array}{l}\text { dvojna, } \\
\text { konvergentna } \\
\text { strgala }\end{array}$ & $\begin{array}{l}\text { visok IL, } \\
\text { Ilam }\end{array}$ \\
\hline II & tipični & $22-40 \%$ & $\begin{array}{l}\text { malo } \\
\text { pestnjakov }\end{array}$ & \\
\hline II & MAT-A & $22-40 \%$ & $\begin{array}{l}\text { veliko } \\
\text { pestnjakov }\end{array}$ & \\
\hline III & $\begin{array}{l}\text { na- } \\
\text { zobčani }\end{array}$ & $3^{-13}$ & $\begin{array}{l}\text { malo } \\
\text { pestnjakov }\end{array}$ & \\
\hline III & MAT-B & $3^{-13}$ & $\begin{array}{l}\text { veliko } \\
\text { pestnjakov }\end{array}$ & \\
\hline
\end{tabular}

Razlike med moustérienom $\mathrm{z}$ acheulénsko tradicijo tipa A in tipa B (MAT-A in MAT-B) je definiral s tem, da prvi vesbuje več pestnjakov in manj nožev s hrbtom, drugi pa več no- žev s hrbtom in manj pestnjakov, kasneje pa je dodal še prehodni MAT AB, ki ga je definiral v Pech de l'Azé I v plasti As in v Pech de l'Azé IV v plasti $F_{3}$ (Bordes 1968, 105; Bordes 1975, 294; Bordes 198I, 77). Do tega prehoda naj bi prišlo v fazi Périgord II v Würmu II. Prav tako je trdil, da je pri mlajšepaleolitskih tipih razvojna težnja od atipičnih v MAT-A proti tipičnim v MAT-B. Prav tako se v MAT-A nahajajo še posamezna strgala tipa La Quina in okoli $20 \%$ nazobčanih orodij ter orodij z izjedo (Bordes in Bourgon I95Ia, IO-23). Izjemo predstavlja industrija v plasti $\mathrm{F}$ in Le Moustier, kjer je veliko strgal, veliko nazobčanih orodij in tudi noži s hrbtom. Zaradi tega je sklepal, da bi se morda lahko zgodilo, da so pri izkopavanjih plasti $F$ pridružili tudi spodnji del plasti $G$, kjer se nahaja nazobčani moustérien (Bordes 1981, 78). Opazil je, da se proti pričakovanjem MAT nahaja tudi v Würmu II (Bordes in Bourgon 1951a, IO-23; Bordes 1953e, 465; Bordes 1961, 804; Bordes in de Sonneville-Bordes 1970, 63-66; Reynolds 1990, 264). Najlepše mu je uspelo definirati razvojne trende od MAT-A proti MAT-B v sklopu plasti $F$ na najdišču Pech de l'Azé IV. Pri primerjavi plasti FI (najstarejša) do F 4 se je pokazalo (Bordes 1975, 30I-4), da število mlajšepaleolitskih elementov narašča od starejše proti mlajši plasti (od 6,5 na I7 \%), da se indeks levallois zmanjšuje (od 9,3 na $5,4 \%$ ), da se zmanjšuje tudi indeks fasetiranih talonov (od 27,6 na 21,3) in da se veča število nožev $s$ hrbtom (od I,2 na 8,5\%).

Predpostavljal je evolucijsko povezavo iz MAT v chatelpérronien na osnovi razvoja moustérienskega noža s hrbtom, ki je izdelan na odbitku, v chatelpérroniensko konico, ki je izdelana na klini (Bordes 1961, 804). Prav tako pa se geografske razprostranjenosti pokrivajo, nobeden od slednjih se ne pojavlja vzhodno od Rhône in oba segata le v severno Španijo (Mellars I973, 273). Podobno idejo o nadaljevanju MAT v châtelperronien, oziroma po njihovi terminologiji še périgordien I, so v okviru bilinearne teorije o razvoju paleolitika $\mathrm{v}$ začetku petdesetih let videli M. Veyrier, E. Beaux in J. Combier, ki so postavili industrijo iz Grotte de Néron kot pre- 
hodno med tipičnim moustérienom in aurignacienom, kar naj bi bilo podobno tudi poziciji industrije iz Abri Audi, ki naj bi bila prehodna oblika med MAT in périgordienom I (Veyrier, Beaux in Combier 1951, 78).

Pri opisu moustériena tipa La Quina je Bordes opozoril na povečanje števila nazobčanih orodij $\mathrm{v}$ njegovih zadnjih fazah, kar je razložil kot vračanje $\mathrm{k}$ izvorni obliki v plasti 3 na najdišču La Micoque. Kronološko ga postavi v Würm I v Combe-Capelle Bas in v Würm II v Combe Grenal (Bordes 1968, 102; Bordes 1981, 78). Že v prvih objavah pa je ugotovil, da je moustérien tipa La Quina mlajši del charentiena (Bordes in Bourgon I95Ia, I2 -23; Bordes 1953e, 465).

Kot značilnost moustériena tipa La Ferrassie je podal veliko število strgal, ki pa jih je manj kot v moustérienu tipa La Quina. To naj bi bilo posledica tehnike odbijanja levallois, ki producira tanke odbitke, na katerih je nemogoče izdelovati debela strgala. Prav tako je nemogoče izdelovati prečna strgala na dolgih odbitkih levallois. V svoji zadnji objavi tik pred smrtjo se je nagibal $k$ temu, da bi moustérien tipa La Ferrassie opisal kot levallois facies moustériena tipa La Quina. Tu je tudi opozoril na težavo ločevanja moustériena tipa La Ferrassie od tipičnega moustériena, obogatenega s strgali. Kronološko je moustérien tipa La Ferrassie postavil v Würm I v Combe-Capelle Bas in v Würm II v Combe Grenal (Bordes 1981, 79).

Nazobčani moustérien je za Bordesa predstavljal »pepelko « moustériena. To industrijo je opisal predvsem zaradi majhnega števila retuširanih orodij ter dejstva, da je število orodij včasih veliko in drugič spet majhno. Iz tega je sklepal, da je $\mathrm{v}$ tej kulturi količina orodij ciklično nihala. Definiral jo je predvsem z odsotnostjo posameznih elementov v orodnih skupkih (Bordes 1968, I02). Nahaja se v Würmu I v Pech de l'Azé ter v Würmu I in II v Combe-Grenal (Bordes 1953e, 463; Bordes 1981, 78-79). Zanimivo je dejstvo, da je pri svojih velikih pregledih večinoma zanemaril podatke o nazobčanem moustérienu, ki jih je dobil pri izkopavanjih - tako je v članku o najdbah iz previsa Armand Chadour- ne opozoril na dejstvo, da se v slednjem vendarle nahaja nekaj razvojnih teženj. Pokazalo se je namreč, da je $\mathrm{v}$ končnem nazobčanem moustérienu opazna težnja k mikrolitizaciji, ki jo je ugotovil v plasti A (Bordes, Fitte in Blanc 1954, 232). V plasti $A-B$ je vseboval veliko strgal, kar je razložil z možnostjo kontaminacije iz plasti $\mathrm{B}$, ki je pripadala charentienu (str. 234). Prav tako je opazil, da končni nazobčani moustérien vsebuje veliko mlajšepaleolitskih elementov, ki zamenjujejo srednjepaleolitske, ter nože s hrbtom in slabo izdelane pestnjake. Ti kažejo na tesno povezanost z MAT (str. 244). Pri tem je opozoril, da se nazobčani moustérien nahaja nad charentienom (Abri Cadourne, Combe-Grenal, Haute-Roche, Grotte du Hyène) in tudi pod njim (Pech de l'Azé II, La Gane, La Ferrassie plast A). To ga je tako zmedlo, da ga je opredelil kot verjetno konvergenco degeneriranih kultur - kot slepo ulico moustériena (str. 248). V svojih zgodnjih delih je sicer zapisal, da se nazobčani moustérien nahaja na koncu moustériena (Bordes in Bourgon I95ıa, 23), vendar je kronološko pozicijo kasneje zanemaril.

Kot najznačilnejši plasti tipičnega moustériena je opisal plasti B in J najdišča Le Moustier, pri čemer je pripomnil, da gre pri plasti J verjetno za tri plasti, od katerih je ena verjetno MAT. Časovno se tipični moustérien nahaja v Würmu I (Combe-Grenal 54, 552, 50, 36) in v Würmu II (Combe-Grenal 31, 30, 29, 28, 7) (Bordes 1953e, 46I; Bordes 198I, 79). Znotraj slednjega je prikazal variabilnost na primeru plasti $4 \mathrm{c2}$ z najdišča Pech de l'Azé II in plasti X $\mathrm{z}$ najdišča Pech de l'Azé IV. Obe sta kronološko uvrščeni v fazo v Würm I - prva vsebuje večje število nazobčanih orodij, druga pa več strgal in ima tudi višji indeks levallois. $\mathrm{Na}$ osnovi kronološke pozicije je sklepal, da sta oba orodna inventarja izdelek istih ljudi, za minimalne razlike v tipološkem sestavu pa naj bi bile krive različne dejavnosti, ki so se vršile na teh dveh krajih (Bordes 1975, 30I-4).

Svojim skupinam je v poznih delih, po letu 1975, kot posebnost dodal še asinipodien, ki je poznan le v fazi Périgord II iz Würma I v Pech de l'Azé IV v plasti J3a. Vsebuje le malo strgal, 
srednje število orodij z izjedami, malo nazobčanih orodij, dosti nožev z naravnim hrbtom in dosti majhnih odbitkov levallois ter odbitke tipa Kombewa. Ime asinipodien je izpeljal iz Pêch podium in Azé - asinus. Zaradi majhnosti orodij so nekateri avtorji to industrijo poimenovali tudi mikromoustérien, Bordes pa je to zavračal, češ da gre pri mikromoustérienu v resnici za industrije, kjer so odbitki majhni zaradi velikosti izhodiščne surovine. Izjemi sta asinipodien in najdbe iz Jabruda, ki jih je A. Rust opisal kot mikromoustérien. Pri teh dveh industrijah velikost orodij ni posledica velikosti surovine, ampak gre za odločitev izdelovalcev, da bodo naredili majhna orodja (Bordes 1975, 297-301; Bordes 1981, 99-100).

Kljub temu da je bila za Bordesa tipološka lista zgolj orodje za klasifikacijo kamenih orodij in ne model arheološke resničnosti (Sackett I988, 416), so ga etnološke primerjave navedle $\mathrm{k}$ domnevi, da so različne zvrsti moustériena po njegovi definiciji ostanki delovanj različnih ljudstev $\mathrm{z}$ individualnimi kulturnimi potezami. $\mathrm{Na}$ osnovi nepravilnega enačenja »orodnega inventarja $\ll \mathrm{z} \gg$ materialno kulturo $\ll$ je podal domnevo o istočasnem bivanju različnih etničnih skupin (Rigaud 1989, I43), pri čemer naj bi bile te skupine majhne, teritorialno vezane, napol ali popolnoma sedentarne in $\mathrm{z}$ močno zavestjo o lastni identiteti, ki je tipe orodij pomagala ohraniti nespremenjene skozi čas (Rolland 1990, 36I). Do tega sklepa prišel, ko je podal tri hipoteze o variabilnosti moustériena. Po prvi naj bi bili različni tipi moustériena povezani s sezonskimi vzorci življenja, kjer bi vsaka zvrst predstavljala opravila v nekem letnem času, vendar je, ker je $\mathrm{v}$ istih kulturnih plasteh odkril ostanke iz različnih letnih časov, to hipotezo opustil. Po drugi hipotezi naj bi vsaka zvrst predstavljala adaptacijo na drugačno okolje, kar bi pomenilo, da so bile spremembe industrij pogojene s spreminjanjem podnebja. Vendar je tudi to hipotezo opustil, ker je $\mathrm{v}$ geoloških plasteh, ki so bile odložene v enakih razmerah, odkril različne industrije oziroma so se iste zvrsti vezale $z$ različno klimo. Da pa ne gre za razlike v širšem okolju, je sklepal po tem, da je dobil podobne rezultate tudi pri primerjavi z Afriko, ki bi po njegovem prepričanju morala imeti radikalno drugačno podnebje. Tako mu je ostala na voljo le še hipoteza, po kateri je vsak tip moustériena ostanek druge skupine ljudi, od katerih ima vsaka svojo tradicijo izdelave orodij, kajti razlike $\mathrm{v}$ načinu življenja so mu dale rezultate le pri moustérienu s tehniko odbijanja levallois in so pokazale, ali je industrija levalloisien ali ne. Tako je sklep, da gre za različne rodove, podkrepil brez dokazov tudi z domnevno, da so ljudje, ki so izdelovali nazobčani moustérien, najraje lovili konje (Bordes 1953e, 465-66; Bordes 196I, 806-IO; Bordes in de Sonneville-Bordes 1970, 71; Binford in Binford 1983, 72-73).

Prav tako pa je glede na tehnologijo odbijanja in tipološki sestav kamenih orodij pokazal, da sta si blizu MAT in nazobčani moustérien. Na drugi strani pa je sestavil tudi podobna para med srednjim in mlajšim paleolitikom, ki naj bi bila po njegovem mnenju, čeprav ni imel dokazov za sočasno bivanje zadnjih nosilcev moustériena in »prvih périgordiencev in aurignaciencev«, odraz vpliva mlajšega paleolitika na moustérien. Tako je povezal MAT in châtelperronien ter moustérien tipa La Quina in aurignacien (Bordes 1953e, 466).

\section{Zaključek}

Osrednja oseba, ki je v največji meri vplivala na potek raziskovanja srednjega paleolitika $\mathrm{v}$ drugi polovici tega stoletja, je bil François Bordes, ki je za razliko od predhodnih avtorjev v svoje delo (in objavljanje), ki ima osnovne sestavine znanstvenega analitskega pristopa, uvedel izjemno sistematiko. Izoliral je fenomen, ga opisal, klasificiral, analiziral njegovo variabilnost in podal sintezo (Jelinek 1988, 199). Zanj je bil moustérien tehnološko-tipološka raven $\mathrm{v}$ kulturnem razvoju človeštva, ki je bila dosežena sočasno po vsem starem svetu (Rigaud 1989, I 45). Njegova tipologija kamenih orodij je bazirala na spremembah orientacije orodja (tehnologija izdelave) in obliki delovnega roba orodja (tehnologija obdelave) (Binford I973, 245), predvsem pa ga lahko štejemo za začetnika statistične obdelave podatkov v 
arheologiji (Brodar 1962-1963, 51). Slednja mu je omogočila premik od takrat aktualnih kvalitativnih primerjav, utemeljenih na analizah vodilnih tipov, k objektivnim kvantitativnim primerjavam paleolitskih industrij (Jelinek 1982, 786). Formalizacija opisov predmetov, ki jo je ustvaril $s$ pregledno tipologijo, analitična klasifikacija ter opis značilnosti so postali predmet raziskave semiologije, obdelava kvantificiranih podatkov, ki je omogočala izdelavo struktur, ki so omogočale interpretacijo (histogrami, kumulativni diagrami, poligoni ...), pa je bila problem statistike in progresivno prihajajoče informatike (Djindjian 2016, 128).

Predvsem pa je opozoril na dejstvo, da je potrebno klasifikacijo artefaktov razširiti na celo serijo formalnih oziroma tehnoloških spremenljivk ter ne omejiti zgolj na tiste, ki jim pripisujemo največjo diagnostično vrednost. Bordezijanska sistematika je pokazala, da je arheološki zapis, oborožen s preglednimi tipološkimi listami ter relativno enostavnimi, vendar učinkovitimi tehnikami statističnega opisovanja, veliko kompleksnejši, kot so to predvidevali tradicionalni pristopi. Še najpomembneje pa je, da ni bil več dojeman kot enostavno linearno zaporedje stereotipnih industrij ampak namesto tega kot kompleks polimorfnih industrijskih kompleksov različnih značilnosti $\mathrm{v}$ istem času na različnih prostorih (Sackett 20I4, 6).

Posledično je bil v njegovih delih moustérien redefiniran kot polimorfen kompleks štirih različnih orodnih kompleksov oziroma tipov skupkov, odkritih interstratificiranih na najdiščih v Perigordu, kar naj bi bila posledica njihove kvazisočasnosti. Interpretacija, ki je vsakemu predstavila domnevnega prednika ter včasih celo domnevala, da gre za različne etnične skupine ali plemena, je bila v ostrem nasprotju s predpostavkami ameriške, antropološko izurjene, arheologije, ki je v slednjih raje videla skupke prostorsko ločenih dejavnosti. Najostrejša, hkrati pa tudi najkonstruktivnejša reakcija na njegovo interpretacijo polimorfične variabilnosti je bila $t$. i. moustérienska debata med njim in Lewisom Binfordom (in Sally Binford). Izpostavljeno je bilo eno izmed poglavitnih vprašanj prazgodovinske (in vsake druge) arheologije - kako lahko $\mathrm{v}$ arheološkem zapisu ločimo med podatki, ki kažejo dejavnosti in etnije, naloge ter skupine, oziroma kako ločiti med tem, kar se je počenjalo, in tem, kdo je to počenjal.

Prav raziskovalni napori Bordesa, to njegovo izboljšanje terenskih tehnik raziskav, standardizacija tipoloških opisov ter razvoj kronoloških metod za določitev starosti, so vodili do prve vseobsegajoče sinteze francoskega srednjega paleolitika. Prav na osnovi njegovega dela danes razumemo, da je potrebno opazovati dva vidika variabilnosti arheoloških zapisov - formalno tipološko variabilnost kamnitih orodij znotraj konteksta ter variabilnost $\mathrm{v}$ relativnih pogostnostih tih tipov orodij med različnimi plastmi oziroma najdišči (Dibble 1987, 34). V desetletju po objavi so njegovo metodologijo opisovanja orodij ter njihovega statističnega vrednotenja sprejeli številni strokovnjaki po svetu, bila pa je deležna tudi redkih kritik (Pradel 1954; Brodar 1962-1963), pri čemer avtorji niso v tolikšni meri kritizirali same metode, kot so svarili pred njeno preradikalno in lokalno neprilagojeno uporabo, na kar pa je pravzaprav opozoril že sam avtor (Bordes I950c; Bordes I953a).

Bordesova aktivna domišljija, ki mu je omogočala absolutno vživitev $\mathrm{v}$ svet prazgodovine je bila najvidnejša $v$ njegovem literarnem delu (Djindjian 2016, 128). Pod psevdonimom Francais Carsac je zaslovel v literarnem svetu kot avtor številnih znanstvenofantastičnih romanov in novel, ki jih je objavil večinoma v 50. in 60 . letih. Na drugi strani pa ga moramo pojmovati tudi kot enega izmed očetov eksperimentalne arheologije. Ne zgolj tehnološko zaradi izjemne sposobnosti izdelovanja kamnitih orodij, ampak predvsem epistemološko zaradi njegovih kontroliranih eksperimentov, s katerimi je preučeval vplive različnih strategij odbijanja na obliko gotovih orodij kot tudi na vrste odpadkov, ki so nastale pri njihovem izdelovanju (Bordes 1947). Prav tako je potrebno omeniti, da je organiziral prvo veliko srečanje strokovnjakov v Les Eyzies-de-Tayacu leta 1964, kjer so se prvič srečali fran- 
coski, kanadski in ameriški prazgodovinarji ter razpravljali ne zgolj o njegovi analitični metodi, ampak so z izvajanjem poskusov predvsem začrtali temelje eksperimentalne arheologije (Jelinek 1965; Texier in Meignen 2012, 136).

\section{Slika 2. Francois Bordes in Don Crabtree. Prvič sta se srečala 1964 v Les Eyziesu ter nato sodelovala celo živ- ljenje.}

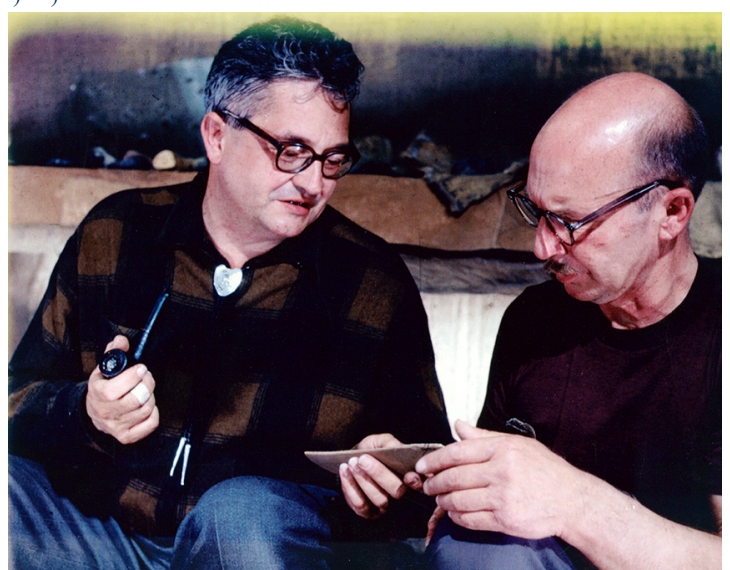

Bordesova monografija oziroma priročnik Typologie du paléolithique ancien et moyen je od prve izdaje leta 196I doživel številne ponovne izdaje v francoskem jeziku. Kljub preživelosti mnogih konceptov, kritik in dopolnitev njegove tipologije se imajo tehnološki in tipološki opisi posameznih orodnih tipov še vedno za temeljni priročnik študija srednjega paleolitika. Tak pomen potrjujejo številne »prevedene « tipologije, ki so njegove primere zamenjale z lokalnimi. Za nas je vsekakor najpomembnejša temeljna publikacija Vide Pohar (1979), ki je v tipologijo kot razlagalne primere vnesla številne najdbe $s$ slovenskih najdišč. Podobno pa je za Hrvaško naredil tudi Ivor Karavanić, ki je leta 1992 objavil predlog osnovnih strokovnih nazivov s tipologijo (Karavanić 1992), tri leta pozneje pa je prevedel še celotno tipološko listo (Karavanić 1995). Ključen prispevek $\mathrm{k}$ dopolnitvi ter hkrati ohranitvi Bordesove tipološke misli vsekakor predstavlja posodobljen priročnik Handbook of Paleolitbic Typology.Vol. I, Lower and MIddle Paleolitbic of Europe, ki sta ga objavila A. Debénath in H. Dibble (1994). Objava v angleškem jeziku je poskrbela za dokončno razširitev klasične tipološke metodologije opisovanja $\mathrm{v}$ takrat že debelo poprocesualni arheološki svet, ki je nagovarjal teme daleč onkraj tradicionalnih obsesij s tipologijo in taksonomijo oziroma $\mathrm{v}$ katerem so posamezni avtorji celo vehementno zahtevali zamenjavo Bordesove tipologije (Bisson 2000). Gre pravzaprav za potrditev njune trditve, da tipologija, ki jo je izdelal Bordes, predstavlja standardno orodje za opisovanje starejše- in srednjepaleolitskih kamnitih orodij v večjem delu starega sveta. Slednje kot tako omogoča komunikacijo med različno usmerjenimi raziskovalci. Posledično sta zagovarjala uporabo terminologije ter napovedala, da je posamezne interpretacije potrebno nadgraditi oziroma zamenjati (Dibble in Debénath I99I, 222). Zgolj dve leti kasneje pa je izšel prikaz neandertalske zapuščine (s poudarkom na zahodni Evropi), ki ga je napisal Paul Mellars. Prav količina citiranosti Bordesovega dela v grand oeuvre moustérienske arheologije jasno kaže pomen njegovega dela za nadaljnji razvoj raziskav srednjega paleolitika ter prazgodovinske arheologije nasploh (Mellars 1996). V njegovi biografiji je Paul Pettit opozoril, da brez njegovega dela Binford ne bi bil zmožen formulirati teorij o obnašanju neandertalcev ter zagnati promocije nove arheologije, Mellars ne bi mogel razviti svojih kronološko-kulturnih sekvenc, Dibble pa ne razlagati dinamike sprememb kamenih orodij ... (Pettit 2009, 203) Čeprav je bil zadnji velikan prejšnjega stoletja, se je dobro zavedal pomena poljudnoznanstvene prezentacije rezultatov dela oziroma je prav $\mathrm{v}$ tem žanru lahko dominiral zaradi svoje izjemne literarne nadarjenosti. Tako moramo njegovo odločitev, da je knjigo $A$ Tale of Two Caves (1972b) objavil zgolj v angleškem jeziku, razumeti kot nagovor širšega občinstva. Hkrati pa je za antropološko izobraženo javnost, ki se je nagibala na Binfordovo stran razprave $\mathrm{z}$ jasnejšo in predvsem enostavnejšo dikcijo, pojasnil kompleksne rezultate svojih terenskih raziskav (Bordes 1955b; Bordes in Bourgon 1950; Bordes in Bourgon 1951b). 
$\mathrm{Na}$ koncu moramo navesti še dve monografiji, ki se v največji meri posvečata Bordesovemu delu prva je doktorska disertacija Jeana-Patricka Loiseauja z naslovom $\gg$ Francois Bordes (1919-198I) et la construction de la Préhistoire dans la seconde moitié du $\mathrm{XX}^{\mathrm{e}}$ siècle «, ki se ukvarja predvsem $\mathrm{z}$ epistemološkimi vidiki njegovega dela oziroma ga opazuje s pozicije zgodovine znanosti (Loiseau 20r4). Druga knjiga z naslovom François Bordes et la Préhistoire, ki sta jo uredila F. Delpech in J. Jaubert, pa je objava prispevkov $s$ kongresa, ki so ga leta 2009 organizirali v Bordeauxu (Delpech in Jaubert 20I2).

\section{Povzetek}

Le malo arheologov je v drugi polovici dvajsetega stoletja tako vplivalo na razvoj metodologije arheološkega dela ter interpretacije prazgodovine kot François Bordes. Na eni strani je sicer pomembna njegova raziskovalna usmeritev v izboljšanje terenskih tehnik raziskav, predvsem pa je revolucionarna njegova standardizacija tipoloških opisov kamnitih orodij oziroma razvoj statističnih metod za primerjavo rezultatov analiz iz posameznih kontekstov. Prav na osnovi njegovega dela razumemo, da je potrebno opazovati dva vidika variabilnosti arheoloških zapisov - formalno tipološko variabilnost kamnitih orodij znotraj konteksta ter variabilnost v relativnih pogostnostih tih tipov orodij med različnimi plastmi oziroma najdišči. Danes, ko so številne njegove interpretacije zastarele oziroma neustrezne, se moramo zavedati kontekstov, v katerih so nastale, ter raziskovalnih vprašanj, na katera so pomagale odgovoriti.

Formalizacija opisov predmetov, ki jo je ustvaril s pregledno tipologijo, analitična klasifikacija ter opis značilnosti so postali predmet raziskave semiologije, obdelava kvantificiranih podatkov, ki je omogočala izdelavo struktur, ki so omogočale interpretacijo (histogrami, kumulativni diagrami, poligoni ...), pa je bila problem statistike in progresivno prihajajoče informatike.

Njegova raziskovalna usmeritev, ki obsega vse od na podlagi praktičnih raziskav razvitega izboljšanja terenskih tehnik arheoloških izkopavanj do standardizacije tipoloških opisov kamnitih orodij ter razvoja kronoloških metod za določitev starosti, je vodila do prve vseobsegajoče sinteze francoskega srednjega paleolitika. Prav na osnovi njegovega dela danes razumemo, da je potrebno opazovati dva vidika variabilnosti arheoloških zapisov - formalno tipološko variabilnost kamnitih orodij znotraj konteksta ter variabilnost v relativnih pogostnostih tih tipov orodij med različnimi plastmi oziroma najdišči. V desetletju po objavi so njegovo metodologijo opisovanja orodij ter njihovega statističnega vrednotenja sprejeli številni strokovnjaki po svetu, bila pa je deležna tudi redkih kritik, pri čemer avtorji niso v tolikšni meri kritizirali same metode, kot so svarili pred njeno preradikalno in lokalno neprilagojeno uporabo, na kar pa je pravzaprav opozoril že sam avtor. Danes poznavanje dela F. Bordesa predstavlja eno izmed ključnih poglavij pri razumevanju zgodovine raziskav stare kamene dobe kot tudi pri razvoju sodobne arheološke teorije.

\section{Summary}

Few archaeologists in the second half of the twentieth century influenced the development of the methodology of archaeological work and the interpretation of prehistory as much as François Bordes. On the one hand, his research orientation towards the improvement of field research techniques is important, but above all his standardization of typological descriptions of stone tools and the development of statistical methods for comparing the results of analyzes from individual contexts are revolutionary. It is on the basis of his work that we understand the need to observe two aspects of the variability of archaeological records - formal typological variability of stone tools within the context and the variability in the relative frequencies of these types of tools between different layers or sites. Today, when many of his interpretations are outdated or inadequate, we need to be aware of the contexts in which they arose and the research questions they helped answer.

Formalization of object descriptions created by an transparent typology, analytical classification and description of characteristics became the subject of research in semiology, and the processing of quantified data, which enabled the production of structures that allowed interpretation (histograms, cumulative diagrams, polygons...), was a problem of statistics and progressively upcoming informatics.

His research orientation, which includes everything from practical research developed improvement of field techniques of archaeological excavations, standardiza- 
tion of typological descriptions of stone tools and development of chronological methods for determining the age, led to the first comprehensive synthesis of the French Middle Paleolithic. It is on the basis of his work that we understand today that it is necessary to observe two aspects of variability of archaeological records - formal typological variability of stone tools within the context and variability in relative frequencies of these types of tools between different layers or sites. In the decade since its publication, his methodology for describing tools and their statistical evaluation has been adopted by numerous experts around the world. But it also received rare criticism, with the authors not criticizing the method as much as warning against its too radical and locally unadopted use, which, in fact, was pointed out by the author himself. Today, knowing the work of F. Bordes is one of the key chapters in understanding the history of Palaeolithic research as well as in the development of modern archaeological theory.

\section{Literatura}

Bachellerie, F., N. Teyssandier, J.-G. Bordes, R. Lippé in V. Guillomet-Malmassari. 2012. »François Bordes et l'interpretation du changement entre le paléolithique moyen et le paléolithique supérieur.«V François Bordes et la Préhistoire, ur. F. Delpech in J. Jaubert, 28I-9I. Pariz: Éditions du Comitédes travaux historiques et scientifiques.

Beyries, S. 1987. Variabilité de l'industrie lithique au moustérien. BAR International Series 328. Oxford: Archeopress.

Binford, L. R. 1973. »Interassemblage Variability - The Mousterian and the »Functional « Argument.«V The Explanation of Culture Change : Models in Prehistory, ur. C. Renfrew, 227-54. Glouchester Crescent: Duckworth Press.

Binford, L. R., in S. R. Binford. 1983. »A Preliminary Analisys of Functional Variability in the Mousterian of the Levallois Facies.«V Working at Archaeology, ur. L. R. Binford, 71-I24. New York: Academic Press.
Bisson, M. S. 2000. »Nineteenth Century Tools for Twenty-First Century Archaeology? Why the Middle Paleolithic Typology of François Bordes Must Be Replaced.«Journal of Archaeological Method and Theory 7 (I): $\mathrm{I}-48$.

Bordes, F. 1947. »Etude comparative des différentes techniques de la taille du silkex et des roches dures.« L'Anthropologie 5I (I2): I-29.

Bordes, F. I950a. »A propos d'une vielle querelle: peut-on utiliser les silex taillés comme fossiles directeurs? « Bulletin de la Sociéte Prébistorique Française 47 (5): 242 J 45 .

Bordes, F. 1950b. »L'évolution buissonnante des industries en Europe occidentle. Considérations théoriques sur le paléolithique ancien et moyen.« L'Anthropologie 54 (5-6): 393-420.

Bordes, F. 1950c. »Principes d'une méthode d'études des techniques de debitage et de $\bullet$ la typologie du paléolithique ancien et moyen.« L'Anthropologie 54 (I): 19-34.

Bordes, F. 1952a. »Stratigraphie du loess et évolution ds industries paléolithiques dans l'Ouest du bassin de Paris. II Évolutiondes industries paléolithiques.« L'Anthropologie 56, 405-52.

Bordes, F. 1952b. »Technique Levallois et 'Levalloisien ancien'.« L'Anthropologie 56: $554-56$.

Bordes, F. 1953a. »Typologie et statistique. Observations sur la note de $\mathrm{M}^{\text {lles }}$ Alimen et Vignar.« Bulletin de la Sociéte Préhistorique Française 50 (I): 74-78.

Bordes, F. 1953b. »Notules de typologie paléolithique. I - Outils Moustériens à fracture volontaire.«Bulletin de la Sociéte Préhistorique Française 50 (4): 224-26.

Bordes, F. 1953C. »Levaloissien et Moustérien.« Bulletin de la Sociéte Préhistorique Française 50 (4): 226-34.

Bordes, F. 1953d. »Notules de typologie paléolithique. II - Pointes levalloisiennes st pointes pseudo-levalloisiennes.« 
Bulletin de la Sociéte Préhistorique

Française 50 (5-6): 311-13.

Bordes, F. 1953e. $\gg$ Essai de classification des industries 'Moustériennes'.« Bulletin de la Sociéte Préhistorique Française 50 (7-8): 457-66.

Bordes, F. 1954. »Notules de typologie paléolithique. III - Pointes moustériennes, racloirs convergents et déjetés, limaces.« Bulletin de la Sociéte Préhistorique Française 51 (7): 336-38.

Bordes, F. 1955a. »Observations sur la note de M. H. Kelley sur la technique de taille 'levalloisienne'.«Bulletin de la Sociéte Prébistorique Française 53 (I-2): II3-I4.

Bordes, F. 1955b. >La stratigraphie de la Grotte de Combe-Grenal, comunne de Domme (Dordogne). Note préliminaire.«Bulletin de la Sociéte Prébistorique Française 52 (7): 426-29.

Bordes, F. 1961. \Mousterian Cultures in France.« Science I34 (3482:, 803-10.

Bordes, F. 1962-1963. »Le Mousterien a denticules. Arheološki vestnik 13-I 4: 4349.

Bordes, F. 1968. Le Paléolithique dans le monde. Pariz: L'Univers des connaissances.

Bordes, F. 1971. »Physical Evolution and Technological Evolution in Man: A Paralellism.«World Archaeology 3 (I): I-5.

Bordes, F. 1972a. »Du Paléolithique moyen au Paléolithique supérieur: continuité ou discontinuité? « V The Origin of Homo Sapiens, ur. F. Bordes, 21I-18. Pariz: Unesco.

Bordes, F. 1972b. A Tale of Two Caves. New York: Harper \& Row.

Bordes, F. 1975. »La gisement du Pech de l'Azé IV. Notes préliminaire. «Bulletin de la Sociéte Préhistorique Française 72, Etudes et travaux I: 293-308.

Bordes, F. 1980. »Le débitage Levallois et ses variantes.«Bulletin de la Sociéte Préhistorique Française 77 (2): 45-49.

Bordes, F. 1981. »Vingt-cinq ans après: le complexe Moustérien revisité.« Bulletin de la Sociéte Préhistorique Française 78 (3): 77-87.

Bordes, F. 1988. Typologie du Paleolithique ancien et moyen. Pariz: Presses du CNRS.

Bordes, F., in M. Bourgon. 1950. »Le gisement du Pech de l'Azé-nord, prise de date et observations préliminaires.«Bulletin de la Sociéte Préhistorique Française 47 (6-8): $38 \mathrm{I}-83$.

Bordes, F., in M. Bourgon. 1951a. »Le complexe Moustérien: Moustériens, Levalloisien et Tayacien.« L'Anthropologie 55 (I): I-23.

Bordes, F., in M. Bourgon. 195 Ib. »Le gisement du Pech de l'Azé-nord. Campagnes 1950-1951: Les couches inférieurs à Rhinoceros Mercki.«Bulletin de la Sociéte Préhistorique Française 48 (II-I2): 520-38.

Bordes, F., in D. de Sonneville-Bordes. 1970. $\gg$ The Significance of Variability in Palaeolithic Assemblages. Word Archaeology 2 (I): 6I-73.

Bordes, F., P. Fitte in S. Blanc. 1954. »L'Abri Armand Chadourne.« Bulletin de la Sociéte Préhistorique Française 5I (5-6): 229-54.

Breuil, H., in H. Kelley. 1954. »Le paléolithique ancien.«Bulletin de la Sociéte Prébistorique Française 5I (I): 9-26.

Brodar, M. 1962-1963. »Pripombe k statističnim metodam za klasifikacijo paleolitskih kultur.« Arheološki vestnik 13I 4: 5I-59.

Debénath, A., in H. L. Dibble. 1994. Handbook of Paleolithic Typology, Vol. r: Lower and Middle Paleolithic of Europe. Philadelphia, PA: University Museum, University of Pennsylvania.

Delpech, F., in J. Jaubert, ur. 20I2. François Bordes et la Préhistoire. Pariz: Éditions du Comitédes travaux historiques et scientifiques.

Dibble, H. L. 1987. »Reduction Sequences in the Manufacture of Mousterian Implements of France.«V The Pleistocene Old World: Regional Perspectives, ur. O. 
Soffer, 33-45. New York; London: Plenum Press.

Dibble, H. L. 1988. »Typologycal Aspects of Reduction and Intensity of Utilisation of Lithic Eesources in the French Mousterian.«V Upper Pleistocene Prehistory of Western Eurasia, ur. $\mathrm{H}$.

L. Dibble in A. Montet-White, I8I-96. Philadelphia, PA: The University Museum, University of Pennsylvynia.

Dibble, H. J., in A. Debénath. 1991. »Paradigmatic Differences in a Collaborative Research Project. $\ll \mathrm{V}$ Perspectives on the Past: Theoretical Biases in Mediterranean HunterGatherer Research, ur. G. A. Clark, 21726. Philadelphia, PA: University of Pennsylvania Press.

Dibble, H., in M. Lenoir. 1995a. »The Development of the Research Design for the Current Excavation.«V The Middle Paleolithic site of Combe-Capelle Bas (France), ur. H. Dibble in M. Lenoir, 7-26. Philadelphia, PA: The University Museum, University of Pennsylvynia.

Dibble, H., in M. Lenoir. 1995b. »Summary of the Industrial Sequence.«V The Middle Paleolithic site of Combe-Capelle Bas (France), ur. H. Dibble in M. Lenoir, 162-73. Philadelphia, PA: The University Museum, University of Pennsylvynia.

Dibble, H. L., in N. Rolland. 1992. »On Assemblage Variability in the Middle Paleolithic of Western Europe.« V The Middle Paleolithic: Adaptation, Behaviour and Variability, ur. H. L. Dibble in P. Mellars, I-28. Philadelphia, PA: The University Museum, University of Pennsylvynia.

Djindjian, F. 2016. »The Revolution of the Sixties in Prehistory and Protohistory.« $\mathrm{V}$ History of Archaeology: International Perspectives, ur. G. Delley, M. DíazAndreu, F. Djindjian, V. M. Fernámdez; A. Guidi in M-A. Kaeser, I25-44. Oxford: Archeopress.
Harrold, F. B. 1988. »The Chatelperronian and the Early Aurignacian in France.« V: The Early Upper Paleolithic, ur. J. F. Hoffecker in C. A. Wolf, BAR International Series 437, 157-91. Oxford: Archeopress.

Isaac, G. 1989. »Squeezing Blood from Stones.«V The Archaeology of Human Origins, G. Isaac, 339-5I. Cambridge: Cambridge University Press.

Jelinek, A. J. 1965. »Lithic Technology Conference, Les Eyzies, France.« American Antiquity 3I (2): 277-79.

Jelinek, A. J. 1982. »François Bordes, 19191981.《 American Antiquity 47 (4), 785-92.

Jelinek, A. J. 1988. »Technology, Typology, and Culture in the Middle Paleolithic.« $\mathrm{V}$ Upper Pleistocene Prehistory of Western Eurasia, ur. H. L. Dibble in A. MontetWhite, 199-210. Philadelphia, PA: The University Museum, University of Pennsylvynia.

Jullien, R. 195I. »Peut-on-parler d"Homo sapiens' au Pleistocene inferieur? « Bulletin de la Sociéte Prébistorique Française 48 (9Iо), 469-73.

Karavanić, I. 1992. »Prijedlog osnovnog strukovnog nazivlja za srednji i mlađi paleolitik.«Opuscula archaeologica 16: 1535.

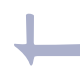
$\sqrt{2}$ $\sqrt{2}$ C 1

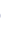
$\longmapsto$ $-$ $(3$ Kavanić, I. I995. »Strukovno nazivlje za donji i srednji paleolitik.« Opuscula archaeologica I9 (I): 7-9.

Kuhn, S. 1995. Moustrian Lithic Technology. An Ecological Perspective. Princeton, NJ: Princeton University Press.

Lacorre, M. T., in F. Lacorre. 1953. »Les Hommes éponymes d'Aïn Métherchem st Combe-Capelle.« Bulletin de la Sociéte Prébistorique Française 50 (4): 258-72.

Loiseau, J.-P. 2014. Francois Bordes (IgI-I98I) et la construction de la Préhistoire dans la seconde moitié du XX $X^{e}$ siècle. Thèse présentée à l'Université de Bordeaux. Bordeaux: HAL.

Loiseau, J.-P. 2015. »Francois Bordes (1919198I) et la construction de la Préhistoire 
dans la seconde moitié du $\mathrm{XX}^{\mathrm{e}}$ siècle. $\ll$ Bulletin de la Sociéte Préhistorique Française II2 (2): 378-79.

Mellars, P. 1968. »The Old Stone Age.« Archaeological Journal I25 (I): 369.

Mellars, P. 1969. »The Chronology of Mousterian Industries in the Périgord Region of South-west France.« Proceedings of the Prehistoric Society 35, 134-7I.

Mellars, P. 1973. $\gg$ The Character of the MiddleUpper Palaeolithic Transition in SouthWest France.« V The Explanation of Culture Change: Models in Prehistory, ur. C. Renfrew, 255-76. Glouchester Crescent: Duckworth Press.

Mellars, P. 1996a, The Neanderthal Legacy. Princeton, NJ: Princeton University Press.

Pettit, P. 2009. »François Bordes.«V Great Prehistorians: 150 Years of Palaeolithic Research, 1850-2009, Special Volume 30 of Lithics: The Journal of the Lithic Studies Society, ur. R. Hosfield, F. Wenban-Smith in M. Pope, 20I-I2. London: Lithic Studies Society.

Pohar, V. 1979. »Tehnika izdelave in tiopologija staro- in srednjepaleolitskega kamenega orodja.« V Porocilo o raziskovanju paleolita, neolita in eneolita $v$ Sloveniji 7 , is-80. Ljubljana: Oddelek za arheologijo Filozofske fakultete Univerze v Ljubljani.

Pottier, G. 1951. »L'Homo sapiens et son ascendance.« Bulletin de la Sociéte Préhistorique Française 48 (7-8): 34I-44.

Pradel, L. 1950. »Comportement physique et intelectuel de l'homme pendant le quaternaire.«Bulletin de la Sociéte Préhistorique Française 47 (5): 250-58.

Pradel, L. 1954. »Le Moustérien.«Bulletin de la Sociéte Prébistorique Française 5I (8): 3543.

Reynolds, T. E. G. I990. »The Middle-Upper Palaeolithic Transition in Southwestern France: Interpreting Lithic Evidence.« $\mathrm{V}$ The Emergence of Modern Humans. An Archaeological Perspective, ur. P. Mellars,
262-75. Edinburgh: Edinburgh University Press.

Rigaud, J.-P. 1989. »From the Middle to the Upper Paleolithic: Transition or Convergence? « V The Emergence of Modern Humans, ur. E. Trinkaus, I24-53. Cambridge: Cambridge University Press.

Rigaud, J.-P., in J. F. Simek. 1987. »Arms Too Short to Box with God.« Problems and Prospects from Paleolithic Prehistory in Dordogne, France.« V The Pleistocene Old World, ur. O. Soffer, 47-6r. New York; London: Plenum Press.

Rodrigue, A. 1989. »Note en faveur d'une modification minime de la liste F. Bordes.«Bulletin de la Sociéte Préhistorique Française 86 (4): 100.

Rolland, N. 1990. »Middle Palaeolithic Socio-Economic Formations in Werstern Eurasia: An Exploatory Survey.« V The Emergence of Modern Humans. An Archaeological Perspective, ur. P. Mellars, 347-88. Edinburgh: Edinburgh University Press.

Sackett, J. R. 1988. »The Mousterian and Its Aftermath.«V Upper Pleistocene Prehistory of Western Eurasia, ur. H. L. Dibble in A. Montet-White, 413-26. Philadelphia, PA: The University Museum, University of Pennsylvynia.

Sackett, J. 20I 4. »François Bordes and the Old Stone Age. «Bulletin of the History of Archaeology 24 (3): I-9.

Tattersall, I. 1995. The Fossil Trail: How We Know What We Think We Know about Human Evolution. New York; Oxford: Oxford University Press.

Texier, P.-J., in L. Meignen. 20I2. »Soxante années de technologie lithique: Étapes marquantes, apports er écueils. $\ll \mathrm{V}$ François Bordes et la Préhistoire, ur. F. Delpech in J. Jaubert, 133-39. Pariz: Éditions du Comitédes travaux historiques et scientifiques.

Tuffreau, A., A.-V. Munat, J.-J.Pouisségur in J. Sommé. 198I. »Les basss terrasses dans 
les vallés du Nord de la France st de la

Picardie: Stratigraphie st Paléolithique.«

Bulletin de la Sociéte Prébistorique

Française 78 (10-12): 291-305.

Vayson, A. 1920. »La plus ancienne industrie de Saint-Acheul.«L'Anthropologie 30 (56): 44I-96.

Veyrier, M., E. Beaux in J. Combier. 1951.

»Grotte de Néron, à Soyons (Ardèche).

Les fouilles de 1950 - leurs ensignements.«

Bulletin de la Sociéte Prébistorique

Française 48 (I-2): 70-78.

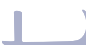

○
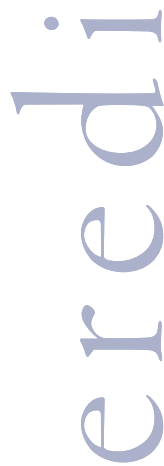